\title{
GONDA György
}

\section{HEGYMENETBEN A VEZETÉSI TANÁCSADÁSI IPAR}

A szerző cikkében a tanácsadási ipar jelenlegi trendjét vizsgálja. Bemutatja azokat a jellemzőket, amivel ez a terület ma rendelkezik. A globális kép bemutatása mellett a hazai helyzetet is elemzi.

Kikerült a hullámvölgyből Európa vezetési tanácsadási ipara, de ez korántsem jelenti azt, hogy belátható időn belül az elmúlt évtizedéhez hasonló fellendülésre kerülne sor. Vége az aranyéveknek - hangoztatják az Atlanti- óceán mindkét oldalán a szakma irányzatainak figyelésével, eredményeinek mérésével foglalkozó kutató intézetek, amelyek emlékeztetnek: a kilencvenes években a világ szolgáltató iparában a távközlés után a vezetési tanácsadás volt a második legdinamikusabban fejlődő ágazat. Az iparág növekedése az elmúlt évtizedben minden évben 15 százalék körül alakult, s jól jellemzi az akkori konjunktúrát, hogy például Európában a bevételek 1994 és 2000 között 11-ről 42,5 milliárd euróra növekedtek (1., 2. táblázat).

\section{1. táblázat}

Az európai piac alakulása (az előző év százalékában)

\begin{tabular}{|c|c|}
\hline 1996 & 14,0 \\
\hline 1997 & 15,0 \\
\hline 1998 & 15,0 \\
\hline 1999 & 15,9 \\
\hline 2000 & 15,5 \\
\hline 2001 & 11,5 \\
\hline 2002 & $-2,0$ \\
\hline 2003 & 3,5 \\
\hline 2004 & 4,0 (becslés) \\
\hline
\end{tabular}

Forrás: FEACO Survey 2005

A vezetési tanácsadási ipar - amely a nemzetközi meghatározások szerint magában foglalja a működési, a vállalati stratégiai, a humán erőforrás, az informatikai és a kiszervezési tanácsadást - bevétele több mint harminc esztendő óta 2002-ben csökkent először. Az amerikai Kennedy Institute adatai szerint abban az esztendőben a világ vezetési tanácsadással foglalkozó cégei 119 milliárd dollár bevételre tettek szert, ez az összeg 6 százalékkal maradt el az előző évitől. Az európai tanácsadási ipar bevétele 2004-ben 47,5 milliárd euró volt, amely összeg a világbevételek több mint 40 százalékát tette ki. Az európai vezetési tanácsadási ágazat 2001-ben még 11,5 százalékkal bővült, egy évvel később a növekedést 2,0 százalékos visszaesés váltotta fel. 2003-ban és tavaly az iparág európai bevételei 3,5 , illetve a nem végleges adatok szerint 4,0 százalékkal növekedtek. (Érdemes megjegyezni, hogy az európai és az amerikai nemzeti vezetési tanácsadási szövetségeket tömörítő szervezeteket, az iparág részletes adatait mintegy másfél éves késéssel teszik közé, 2005 nyarán például csak a 2003-as esztendôről álltak rendelkezésre végleges statisztikák és kimutatások.)

Hasonló irányzat jellemzi a hazai vezetési tanácsadási ágazatot is. A Vezetési Tanácsadók Magyarországi Szövetsége - VTMSZ - adatai szerint 2002-ben az előző évi 10,0 százalékos növekedés után csak 1,5 százalékkal bővült a piac, 2003-ban pedig 2,0 százalékos volt a visszaesés.

Számos elemzés készült a drámai nemzetközi viszszaesés okairól, amelyek szinte egybehangzóan megállapítják: a hullámvölgyet nemcsak konjunkturális okok idézték elő, hanem egyéb tényezők is. Ezek közül érdemes kiemelni, hogy a közös projektek során a vezetési tanácsadók sok ismeretet, metodikát és „mesterfogást” adtak és adnak át ügyfeleiknek, akik egyes tanácsadói feladatokat ma már maguk is képesek megbízható színvonalon elvégezni. Sokan azt emlegetik, hogy az elmúlt másfél-két évtizedben a szakma jelentősen rontotta saját jövőbeli üzleti esélyeit az 
ügyfelek projektekbe való túlzott bevonásával, ráadásul igen sok vezetési tanácsadó helyezkedett és helyezkedik el a többnyire biztosabb megélhetést biztosító ügyfeleknél.

Nem véletlen az sem, hogy mind több globális és nagyvállalat rendelkezik saját vezetési tanácsadó részleggel, amelyek egy része külső ügyfeleknek is nyújt mind gyakrabban szolgáltatásokat. Gondot okoz az új, úgynevezett húzótermékek hiánya is, jó ideje ugyanis már nincsenek olyan, úgynevezett áttörést hozó ötletek, amelyek újabb lendületet adnának a szakmának. A nyolcvanas kilencvenes években az ágazatnak jelentős és tartós bevételeket hozó húzóterméknek számított többek között a vállalatirányítási rendszerek (ERP), az üzleti folyamatok átalakítása (BPR), a logisztikai tanácsadás, valamint az ügyfél-menedzselési (CRM) rendszerek kialakítása és a kapcsolódó tanácsadás.

2. táblázat

Vezetési tanácsadási bevételek 2003-ban, a GDP százalékában

\begin{tabular}{|l|l|}
\hline Nagy-Britannia & 0,96 \\
\hline Németország & 0,44 \\
\hline Európai Átlag & $\mathbf{0 , 4 2}$ \\
\hline Magyarország & 0,38 \\
\hline Hollandia & 0,35 \\
\hline Szlovénia & 0,33 \\
\hline Spanyolország & 0,31 \\
\hline Svájc & 0,31 \\
\hline Franciaország & 0,28 \\
\hline Portugália & 0,26 \\
\hline Észak-Európa & 0,24 \\
\hline Románia & 0,23 \\
\hline Ausztria & 0,20 \\
\hline Belgium & 0,18 \\
\hline Olszország & 0,15 \\
\hline Lengyelország & 0,15 \\
\hline Görögország & 0,12 \\
\hline Oroszország & 0,04 \\
\hline
\end{tabular}

Forrás: Feaco Survey 2005

Persze időközben jócskán átalakultak a vezetési tanácsvevők igényei, elvárásai is. Az ügyfelek olyan holisztikus, integrált tanácsadási tevékenységre tartanak igényt, amely problémáikra, üzleti lehetőségeikre egyedileg megtervezett, majd implementált megoldásokat kínál. A vezetési tanácsadókhoz fordulók szakértelmet, minőséget, gyakorlati jártasságot, tapasztalatot várnak el pénzükért. Mind élesebbé válik a határ a vezetési tanácsadás és az úgynevezett megoldási tanácsadás (solution consulting) között. Ez utóbbi inkább iparági tanácsadást jelent, tehát döntően a termelési és szolgáltatási ágazatok szakmai kérdéseire, sajátosságaira, megoldásaira vonatkozik.

Az elmúlt 2-3 évben számottevő átrendeződés vette kezdetét a globális és az európai vezetési tanácsadási ágazat cégei kọrében. Számos, korábban neves, jól ismert vállalat szűnt meg, hagyta abba tevékenységét vagy felvásárolták, illetve más cégekkel egyesült. A 2001-es Enron-botrány, valamint a következő évben elfogadott Sarbanes-Oxley törvény (amely többek között a könyvvizsgáló szakmát sem hagyta érintetlenül) után az auditor világcégek összeférhetetlenségi okok miatt sorra értékesítették vezetési tanácsadási üzletágukat. A PricewaterhouseCoopers vezetési tanácsadási üzletágát például az IBM vásárolta meg, s a példák sorát hosszasan lehetne folytatni.

A nemzeti vezetési tanácsadó szövetségek európai föderációja, az 1960-ban alapított, brüsszeli székhelyú FEACO adatai szerint folytatódik a polarizáció a nagy tanácsadási világcégek és a kis, egy-egy szakterületre szakosodott vállalatok között. 2000-ben az európai piacon a 20 legnagyobb vezetési tanácsadási cég érte el a bevételek 49,4 százalékát, 2003-ban ez az arány már elérte az 56,0 százalékot. Ugyanebben az időszakban a közepes méretű vállalatok részaránya 41,2-rôl 28,6 százalékra zuhant. Jól jelzi a kis tanácsadó cégek létjogosultságát, hogy piaci részarányuk három esztendő alatt 9,4-ről 15,4 százalékra bővült. Ez utóbbi adat arra hívja fel a figyelmet, hogy a kis vezetési tanácsadók közül azok az úgynevezett ,résjátékosok" (nich players) számíthatnak elsősorban sikerre, amelyek szolgáltatásai speciálisak, lehetőleg egyediek.

A vezetési tanácsadási iparágat a világban, napjainkban általában az egyenetlenül eloszló túlkapacitások, a továbbra is nehéz üzletszerzés, a kíméletlen verseny és a tanácsadói díjak folyamatos csökkenése jó esetben stagnálása jellemzi. A tapasztalatok szerint a vállalatok, az intézmények és a közületi szektor minőségi igényei, elvárásai a tanácsadók felé igen magasak, s akkor vesznek igénybe vezetési tanácsadókat, ha azok mérhetô értéket szállítanak, testre szabott megoldásokat kínálnak, s olyan ismeretekkel rendelkeznek, amelyek a tanácsvevőnél hiányoznak. S persze az is feltétele újabban a megbízásnak, hogy a tanácsadó anyagilag is vállaljon részt a projektek kockázatában (sikerdíj) és az általa javasoltak megvalósításában.

A világ első számú vezetési tanácsadási piaca továbbra is az Egyesült Államok, ahol az ágazat bevé- 
telei a statisztikák tanúsága szerint megközelítik a bruttó hazai termék 1 százalékát, 2003-ban, Európában ez az arány 0,42 százalék volt. Az európai átlagnál Nagy-Britanniában és Németországban volt magasabb az arány $(0,96$, illetve 0,44 százalék), a harmadik helyen Magyarország állt a GDP 0,38 százalékával.

Az európai vezetési tanácsadási piac - $\mathrm{s}$ ezen belül a magyar is - jól mutatja a globális irányzatokat, kínálatot, keresletet, a szerkezet változásait.

2003-ban, Európában mintegy 95 ezer vezetési tanácsadási cég működött 310 ezer tanácsadóval. Magyarországon a vezetési tanácsadással foglalkozó vállalatok száma ugyanebben az esztendőben meghaladta a 400-at, a tanácsadóké pedig a háromezret. A leginkább „tanácsadósodott” ország Európában Nagy-Britannia és Németország, amelyek a 47,5 milliárd eurós összbevételből 31,2, illetve 27,7 százalékot tudhatnak a magukénak. Kelet-Európa a bevételek 3,1 százalékával, mintegy 1,5 milliárd euróval részesedik, ezen belül a magyar vezetési tanácsadási ipar összbevétele mintegy 215 millió euró volt. (3. táblázat).

3. táblázat

Az európai tanácsadási bevételek megoszlása 2003-ban, százalékban

\begin{tabular}{|l|r|}
\hline Nagy-Britannia & 31,2 \\
\hline Németország & 27,6 \\
\hline Franciaország & 11,8 \\
\hline Spanyolország & 5,5 \\
\hline Észak-Európa & 4,8 \\
\hline Olaszország & 4,2 \\
\hline Hollandia & 4,1 \\
\hline Kelet-Európa & 3,1 \\
\hline Svájc & 2,5 \\
\hline Belgium & 1,3 \\
\hline Ausztria & 1,3 \\
\hline Portugália & 0,8 \\
\hline Görögország & 0,4 \\
\hline Egyéb Európa & 1,3 \\
\hline
\end{tabular}

Forrás: Nemzeti statisztikák

A statisztikák szerint 2003-ban Kelet- és KözépEurópában növekedett a legnagyobb mértékben, 14 százalékkal a vezetési tanácsadói piac. A régiót NagyBritannia és Spanyolország követi 14, illetve 6 százalékos bevétel növekedéssel. Viszont igen kedvezőtlen volt az üzletmenet 2003-ban a francia, a svájci és a belga vezetési tanácsadók számára: ezeken a piacokon a bevételek $10,8,5,0$, illetve 4,5 százalékkal maradtak el az előző évitől.
Sokat elárul egy-egy gazdaságról, hogy szereplői mennyit költenek egy esztendőben vezetési tanácsadásra. Nagy-Britanniában 14,8, Németországban 13,1, Olaszországban és Hollandiában 2-2 milliárd eurót fordított a magán és a közületi szektor vezetési tanácsadási szolgáltatások igénybevételére. Ugyanerre a célra 2003-ban, Svédországban 825, Ausztriában 600, Portugáliában 375, Lengyelországban 240, Görögországban 205, Romániában pedig 95 millió eurót költöttek. (Az oroszországi vezetési tanácsadók bevétele becslések szerint megközelítette a 700 millió eurót.)

Jelentős átalakulás történik ebben az évtizedben a tanácsvevői keresletben is, s erről a bevételek szerkezetének alakulása is ,árulkodik”. Európában ugyan továbbra is az informatikai tanácsadásból származik az iparág legnagyobb bevétele, az IT-ágazat részesedése azonban a tanácsadási „tortából” rohamosan csökken. Az ezredfordulón még a tanácsadási bevételek mintegy 40 százaléka származott rendszerfejlesztési és integrációs tanácsadásból, tavaly ez az arány alig haladta meg a 28 százalékot.

Ugyanebben az időszakban szintén mérséklődött a vállalati stratégiai tanácsadás részaránya és fontossága. Ebbe a „műfajba” tartozik többek között a szervezetfejlesztés, a cégfelvásárlásokkal és összeolvadásokkal kapcsolatos komplex jellegű vezetési tanácsadás, a pénzügyi tanácsadás, valamint az értékesítési, a marketing és a vállalati kommunikáció, s nem utolsó sorban a stratégiai tervezés. Két esztendő alatt a stratégiai tanácsadás részesedése 25,8-ról 17,4 százalékra esett vissza a bevételekben.

Amikor az általános és az ágazati konjunktúra kedvezőtlen a vállalatok számára, előtérbe kerül a működési tanácsadás, amely többek között a hatékonyság javítását, a költségek mérséklését, az üzleti folyamatok újrafogalmazását, a változások megfelelő kezelését hivatott szolgálni. Ez a tanácsadási ág foglalkozik a mind inkább előtérbe kerülő ügyfélkezelési és logisztikai kérdésekkel, amelyek számottevően befolyásolják a versenyképességet, a piaci pozíciók megtartását és javítását. Nem véletlen, hogy a világgazdaság gyengélkedése idején a múködési tanácsadás részesedése az iparágon belül 20,0-ról 26,9 százalékra növekedett, $s$ ezzel az informatika után a második legjelentősebb bevételi forrása lett a vezetési tanácsadással foglalkozó vállalatoknak.

A tanácsadási iparág változási irányának kifejezője az úgynevezett kiszervezési tanácsadás (outsourcing) igen dinamikus fejlődése. Az egyes tevékenységek és erőforrások kihelyezése országon belül vagy országon 
kívül növeli a vállalatok hatékonyságát és fokozza a versenyképességet. A kiszervezési szolgáltatások sikertörténetét jól jelzi, hogy részaránya három esztendő alatt 8-ról 17,4 százalékra bővült az európai tanácsadási piacon, $\mathrm{s}$ az outsourcing 2003-ban már 8,25 milliárd eurós bevételi nagyságrendet képviselt.

Hasonló sikert tudhat a magáénak az emberi erőforrással kapcsolatos tanácsadás is. Ennek az is az oka, hogy az intézmények és a vállalatok a korábbinál nagyobb figyelmet fordítanak az új munkatársak kiválasztására, a teljesítmény mérésére és értékelésére, az ösztönzési rendszer „finomra-hangolására”, a szakmai és egyéb kompetenciákkal kapcsolatos oktatásra, továbbképzésre, a HR stratégiára, a karriertervezésre, az elbocsátások és a nyugdíjazások emberi tényezőinek „kezelésére”. 2001-ben az emberi erőforrás tanácsadás részesedése a bevételekből 4,5 százalék volt, két évvel később pedig ennek több mint a kétszerese. Ez az arányváltozás is jól mutatja, hogy a XXI. században a munkaadók számára mindinkább az emberi tőke jelenti a legfontosabb értéket (4. táblázat).

4. táblázàt

Európai tanácsvevői kiadások 2003-ban, milliárd euróban

(zárójelben az előző évi érték)

\begin{tabular}{|l|l|}
\hline Nonprofit és kormányzat & $6,7(4,7)$ \\
\hline Bank & $5,0(6,3)$ \\
\hline Energia és közmű & $4,8(4,3)$ \\
\hline Távközlés, média és szórakoztatóipar & $4,7(4,3$ \\
\hline Nagy- és kiskereskedelem & $4,0(4,0)$ \\
\hline Vegyipar & $3,4(3,9)$ \\
\hline Biztosítás & $3,3(3,8)$ \\
\hline Légi- és hadiipar & $2,6(2,0)$ \\
\hline Szállítás & $1,9(2,0)$ \\
\hline Autóipar & $1,9(2,5)$ \\
\hline Fogyasztási cikkek & $1,9(1,9)$ \\
\hline Személyes és üzleti szolgáltatások & $1,7(1,2)$ \\
\hline Egészségügy és gyógyszeripar & $1,6(1,3)$ \\
\hline Európai Unió & $0,6(0,5)$ \\
\hline Egyéb & $3,3(3,9)$ \\
\hline
\end{tabular}

Forrás: Feaco Survey 2004-2005

Érdekes képet mutat a tanácsvevői piac alakulása. (4. táblázat) A FEACO statisztikái szerint az európai vezetési tanácsadási bevételek 14,1 százaléka a nonprofit és a kormányzati ágazatból származott, ezt követte a bankszektor 10,5 százalékkal. (Érdemes megjegyezni, hogy a korábbi években a tanácsvevők ágazati listáját szinte kivétel nélkül a bankágazat vezette.) A tanácsadói bevételek 10,2 százaléka származott az energia- és a közműiparból, a média, távközlési és szórakoztatóipari ágazat részesedése 9,9 a nagy- és kiskereskedelemé pedig 8,4 százalék volt. A sorból érdemes még kiemelni az autóipar és az egészségügy számára végzett tanácsadást, amelyek az összbevételben 4,0 és 3,4 százalékot képviseltek. Meglepő, hogy az Európai Unióval kapcsolatos vezetési tanácsadás a bevételekből mindössze 1,2 százalékkal ( 0,6 milliárd euró) részesedett.

Európában tehát továbbra is pénzintézeti szektor a legnagyobb tanácsvevő, hiszen a bankok már említett részesedése mellett a biztosítók a bevételekhez 7,0 százalékkal járultak hozzá.

Az ügyfelek a vezetési tanácsadóktól elvárják, hogy rendelkezzenek számottevő iparági ismerettel az adott területen, hiszen e nélkül szinte lehetetlen szektorális vezetési tanácsadást nyújtani. Nem véletlen, hogy a tanácsadási vállalatok mind nagyobb számban alkalmaznak iparági szakértőket, akik specialistaként a hagyományos, generalista vezetési tanácsadókkal együtt kiváló szakértői csapatot alkotnak. Sok esetben az iparági szakértők a tanácsadási cégekhez az ügyfelektől és a potenciális ügyfelektől érkeznek, s az sem ritka, hogy egy-egy vezetési tanácsadó korábbi ügyfelénél „landol” munkavállalóként. (A szakma véleménye szerint azok a legjobb, a leginkább megoldásorientált vezetési tanácsadók, akik a ,pult” mindkét oldalán - tanácsadóként és tanácsvevőként - sok évet töltenek el.)

A változó gazdasági és piaci környezet és helyzet folyamatosan új ,műfaji” kihívások elé állítja a vezetési tanácsadási ágazatot, s ezek a kihívások jelentik a szakma számára a megújulást. Természetesen az eddigi, döntően hagyományos vezetési tanácsadási szolgáltatásokra is lesz kereslet az előrejelzések szerint, de itt a növekedés csak kis mértékủ lesz, egyes szolgáltatások keresletében pedig stagnálás, sőt, további visszaesés várható.

Ez utóbbi kategóriába tartozik többek között az üzleti folyamatok átalakítása (BPR), a költségcsökkentési tanácsadás, valamint a szervezetfejlesztés. A fizetőképes kereslet megcsappanásában az is komoly szerepet játszik, hogy a tanácsvevők ezekre a feladatokra saját alkalmazásban álló tanácsadó munkatársakat vesznek igénybe.

$\mathrm{Az}$ új szolgáltatások közül világszerte igen dinamikusan bővülő kereslet mutatkozik többek között a már említett ügyfélkezelési, logisztikai tanácsadásra, a változáskezelésre, a teljesítményértékelési rendszerek- 
re, valamint a kiszervezésre. (Magyarországon ez utóbbi szolgáltatás egyelőre csak a tanácsadási bevételek alig mérhető, egy százalék alatti részét képviseli.)

Új „,műfajként” mind több vállalat veszi igénybe a vállalatkormányzási (corporate governance) tanácsadást, amelynek jelentősége az Enron-botrány és az azt követő szigorúbb szabályozások bevezetése óta nőtt meg. A corporate governance tanácsadás kiterjed többek között szervezeti, etikai, finanszírozási, cégvezetési, teljesítményértékelési kérdésekre is.

A magyarországi vezetési tanácsadási és tanácsvevői piac fő vonalaiban a nemzetközi irányzatokat tükrözi. 2003-ban a VTMSZ tagvállalatai bevételeinek 49,0 százaléka származott stratégiai tanácsadásból, a működési tanácsadás részesedése 28,0 százalék volt. A HR-tanácsadás a bevételek 20,0, az informatikai pedig 3,0 százalékát képviselte. Ez utóbbi ágazat igen alacsony részaránya azzal magyarázható, hogy a VTMSZ tagjai között kevés az informatikai tanácsadó cég.

Tavalyelőtt Magyarországon a nonprofit és a kormányzati szféra vezette a tanácsvevők sorát mintegy 20 százalékos részesedéssel. Az energia és a közműszektorból származott a vezetési tanácsadási bevételek 15 százaléka, a fogyasztási cikkeket gyártó ipar pedig 14 százalékkal járult hozzá a bevételekhez. A felmérések szerint nőtt a tanácsvevési kereslet az egészségügyben, a vegyiparban, a szállítási ágazatban, valamint a médiaiparban. Az előző évekhez képest viszont csökkent a vezetési tanácsadás iránti igény a távközlési és a banki ágazatban.

Magyarországon is növekedett az igény az integrált, komplex szolgáltatások, a rövidebb projektek, a professzionális projektvezetés és a mérhető eredmények iránt. A vezetési tanácsadási cégek között tovább növekedett és élesedett az árverseny, amiből végső soron az ügyfelek profitáltak, ugyanis csökkentek (egyes cégeknél jó esetben stagnáltak) a tanácsadási díjak (5. táblázat).

A VTMSZ tagjainak véleménye szerint a szakmában mind nagyobb számban jelennek meg a kontárok, akik szakmai felkészületlenségükkel, gyenge minőségű tevékenységükkel, sok esetben etikátlan magatartásukkal, valamint dömping jellegű árképzésükkel zavart idézhetnek elő a tanácsvevők soraiban is. Nem véletlen, hogy a VTMSZ új stratégiájának fontos eleme a szakmaiság erősítése, vagyis az ügyfelek és a potenciális tanácsvevők meggyőzése arról, hogy minőségi tanácsadást, szakértelmet, etikus magatartást a szövetség tagvállalatai tudnak garantálni. A VTMSZtagság amolyan védjegy, garancia az ügyfelek számára, hiszen a szövetség tagjainak nagyon szigorú felvételi követelményeknek kell megfelelniük, emellett pedig tevékenységüket a nem kevésbé szigorú etikai kódex és ajánlások keretei között végzik. További garanciát jelent, hogy komoly felkészítés és vizsga nyomán a VTMSZ adja ki a Bejegyzett Vezetési Tanácsadó (Certified Management Consultant, CMC) címet a brit vezetési tanácsadási intézet normáinak megfelelően. (Magyarországon mintegy 160 vezetési tanácsadó rendelkezik CMC-vizsgával.)

Visszatérve a hazai piac irányzataira: a tagjai körében a VTMSZ nemrégiben végzett felmérést a 2004-es üzleti évről. Az előzetes adatok arról tanúskodnak, hogy tavaly idehaza is megélénkült a piac, s az ágazat cégei mintegy öt százalékkal növelték bevételüket. A szolgáltatások rangsorát továbbra is a vállalati stratégiai tanácsadás vezeti 38 százalékos bevételi részesedéssel. Növelte részarányát, 37 százalékra, a működési tanácsadás, a humán erőforrás-tanácsadás az összbevétel 21 százalékát tudhatta a magáénak. Az informatikai tanácsadás mintegy 4 százalékot képviselt a 225 millió eurót meghaladó bevételekben.

A nem végleges, de a tendenciákat jól kifejező adatok azt mutatják, hogy az előző évekhez képest kis mértékben módosult a tanácsvevők sorrendje. 2004-ben a vezetési tanácsadási bevételek 18 százaléka származott az energia és közüzemi szektorból, ezt követte 16 százalékkal a fogyasztási cikk ágazat. A nonprofit és kormányzati szféra 13 , a pénzügyi szektor 12 , a távközlési, média és szórakoztatóipari ágazat pedig 11 százalékot képviselt a bevételekben, míg az Európai Unióval kapcsolatos tanácsadás mindössze egy százalékot. (Ez utóbbi kategória nem tartalmazza a pályázatírási tevékenységet.)

A vezetési tanácsadási ágazat nemzetközi trendjeit elemző Kennedy Institute szerint idén és jövőre az „aranyévekhez” képest szerény, jó esetben évi 3-5 százalék körüli növekedésre számíthat a világ vezetési tanácsadási ipara. Az ágazat nagy vállalatai - amelyeket a szakma szupermarketetnek hív a szolgáltatások széles kínálata miatt - már néhány éve ugyan veszítenek korábbi pozícióikból, a következő esztendőkben üzleti szempontból várhatóan még mindig a nagyobb tanácsadási cégek lesznek sikeresebbek. Mellettük azok a kisebb vállalatok is számíthatnak piaci sikerre, amelyek speciális tudást és tanácsadási szolgáltatásokat kínálnak. Az új megbízásokban várhatóan mind nagyobb hangsúlyt kap majd az új profitforrások felkutatása. 
Adatok a magyar piacról

\begin{tabular}{|c|c|c|c|}
\hline & 2001 & 2002 & 2003 \\
\hline Bevétel (millió euró) & 217 & 220 & 215 \\
\hline Növekedés százalékban & 10,0 & 1,5 & $-2,0$ \\
\hline Vezetési tanácsadó cégek száma & 320 & 220 & 420 \\
\hline Vezetési tanácsadók száma & $\cdot 3100$ & 3100 & 3500 \\
\hline $\begin{array}{l}\text { Bevételek megoszlása } \\
\text { százalékban }\end{array}$ & $\begin{array}{l}\text { Vállalati stratégia }(44,0) \text {, } \\
\text { Működési tanácsadás }(27,2) \text {, } \\
\text { IT tanácsadás }(9,9) \text {, } \\
\text { HR tanácsadás }(17,9) \text {, } \\
\text { Kiszervezési tanácsadás }(1,0)\end{array}$ & $\begin{array}{l}\text { Vállalati stratégia }(39,0), \\
\text { Működési tanácsadás }(28,0) \text {, } \\
\text { IT tanácsadás }(9,0) \text {, } \\
\text { HR tanácsadás }(24,0)\end{array}$ & $\begin{array}{l}\text { Vállalati stratégia }(49,0) \text {, } \\
\text { Múködési tanácsadás }(28,0) \text {, } \\
\text { IT tanácsadás }(3,0) \text {, } \\
\text { HR tanácsadás }(20,0)\end{array}$ \\
\hline $\begin{array}{l}\text { Főbb tanácsvevő ágazatok } \\
\text { százalékban }\end{array}$ & $\begin{array}{l}\text { Feldolgozó ipar }(18,0), \\
\text { Távközlés }(14,0), \\
\text { Egészségügy }(11,0)\end{array}$ & $\begin{array}{l}\text { Nonprofit és kormányzat }(14,0) \text {, } \\
\text { Fogyasztási cikkek }(14,0) \\
\text { Energia és közmû }(12,0)\end{array}$ & $\begin{array}{l}\text { Nonprofit és kormányzat }(20,0) \text {, } \\
\text { Energia és közmű }(15,0), \\
\text { Fogyasztási cikkek }(14,0)\end{array}$ \\
\hline
\end{tabular}

Forrás: VTMSZ éves statisztikák.

A FEACO várakozásai szerint idén Európában a vezetési tanácsadási piac 3-4 százalékos bővülésével lehet számolni. A megrendelések a legdinamikusabban várhatóan az ügyfélkapcsolat-irányítás, a logisztikai, a humán erőforrás menedzsment és a kiszervezési tanácsadás területén növekszenek. Az európai szövetség szerint jelentős tanácsadási kereslet várható a távközlési, média, szórakoztatóipar, banki, biztosítói és egyéb szolgáltatási ágazatokban.

A magyar piacon a szakemberek 4-5 százalékos növekedésre számítanak 2005-ben. Az év első felében mind a kormányzati (közigazgatási), mind a vállalati szektor növelte vezetési tanácsadásra fordított kiadásait, s növekedett a tanácsadási szolgáltatások vásárlása közbeszerzésen keresztül is. Továbbra is a kisebb projektek jellemzik a piacot, de beindult néhány olyan program, amely többéves feladatot jelent a győztes tanácsadóknak. Tovább növekedett a szabadúszó, magukat tanácsadónak nevező piaci szereplők száma, kérdés azonban, hogy a piacnál gyorsabban bővülő kínálat milyen hatással lesz a minőségre és az árszintre. Annyi azonban bizonyos, hogy a hazai piacon feszültségek várhatóak egyrészről a fizetôképes keresleti és a kínálati oldal között, másrészről pedig a szakemberkínálat (a szerző nem a kontárok bővülő körére gondol) területén. Ez utóbbiról érdemes megjegyezni, hogy 2006-ban több felsőoktatási intézmény szándékozik BA, MSc és posztgraduális tanácsadóképzést beindítani.

\section{Felhasznált irodalom}

FEACO Survey 2000, 2001, 2002, 2003, 2004, 2005

FEACO konferenciák (Lisszabon, Ljubljana, Athén) írásos anyagai és elốadásai

FEACO Executive Committee féléves konjunktura elemzései

Kennedy Institute időszakos publikációi a vezetési tanácsadási ipar helyzetéről

VTMSZ piaci felmérések 2000, 2001, 2002, 2003, 2004, 2005

A szerzổ korábbi tanulmányai, előadásai: www.feaco.com, www.vtmsz.hu 